\title{
Sensory and physicochemical evaluation of acerola nectar sweetened with sucrose and different sweeteners
}

Mariana Borges de Lima DUTRA ${ }^{1,2 *}$, Helena Maria André BOLINI ${ }^{2}$

\begin{abstract}
This paper aims to evaluate the physicochemical characteristics, sensory acceptance, and purchase intent of acerola nectar sweetened with sucrose and other sweeteners (neotame, sucralose and stevia extracts with 40\%, 60\%, 80\%, and 95\% rebaudioside A). The analyses were carried out for $\mathrm{pH}$, soluble solids, total titratable acidity, ascorbic acid, and colorimetry ( $\left.\mathrm{L}^{\star} \mathrm{a}^{\star} \mathrm{b}\right)$. The acceptance test was performed by 120 consumers who evaluated the appearance, aroma, flavor, texture, and overall impression of the samples using a $9-\mathrm{cm}$ unstructured hedonic scale. Furthermore, the consumers were asked to rate overall purchase intent along the scale anchored with (1) "would definitely not purchase" to (5) "would definitely purchase." The results were evaluated using analysis of variance/Tukey test and the internal preference mapping technique. The acerola nectar samples did not differ significantly ( $p>0.05)$ between themselves in terms of vitamin $\mathrm{C}$ content and total titratable acidity. As for appearance and aroma, there was no significant difference $(\mathrm{p}>0.05)$ between the samples, and as for flavor and overall impression, the most accepted samples were those with sucrose and sucralose. The internal preference mapping indicated that the most accepted samples were those with sucrose, sucralose, and neotame were. The highest frequency of positive purchase intent scores was observed for sucrose and sucralose.
\end{abstract}

Keywords: Stevia rebaudiana; sucralose; neotame; Malpighia emarginata DC.

\section{Introduction}

Acerola is a tropical fruit with great economic and nutritional potential due primarily to its high content of vitamin $\mathrm{C}$ associated with the carotenoids and anthocyanins present in the fruit (MEZADRI et al., 2008). Additionally, its easy cultivation, pleasant flavor and aroma, and high potential for industrial use enable the simultaneous development of multiple products, which promotes job creation (MAIA et al., 2003).

Consumption of fruit juices and nectars has gained popularity in Brazil and in the world. The products derived from this fruit contribute significantly to a healthy life through their content of vitamins, minerals, antioxidants, and phytochemical compounds (GUL; AKPINAR; DAGISTAN, 2012). Acerola nectar is widely consumed in many countries, mainly because of its pleasant flavor and high vitamin $\mathrm{C}$ content.

Due to the need to replace sucrose with sweeteners, interest in studying these substances has been growing. Individual factors of these sweeteners, such as the intensity and duration of sweetness, and the aftertaste or lack thereof are fundamental for their use, acceptance, and selection among consumers (MARCELLINI; CHAINHO; BOLINI, 2005).

Neotame is a strong sweetener that is 7,000 to 13,000 sweeter than sucrose. It can be used to sweeten foods and beverages as well as to modify and enhance the flavor of foods (FLAMM et al., 2003). The profile of the sweetness from neotame is similar to that of sucrose (BANNWART et al., 2007). Similarly to what occurs with other sweeteners, the sweetness potency of neotame depends on its concentration and the food or beverage to which it will be added (SEDIVÁ; PANOVSKÁ; POKORNY, 2006).

Sucralose is a high-intensity sweetener derived from sucrose. Its pleasant sensory profile, high water solubility, and physicochemical stability enable its use in acidic foods and thermally processed products without loss of sweetness (BASU; SHIVHARE; SINGHT, 2013). Furthermore, sucralose is considered an option for improving quality of life for the diabetic population (VIBERG; FREDRIKSSON, 2011).

Among natural sweeteners, stevioside and rebaudioside A can be highlighted. They are the main diterpene glycosides extracted from the leaves of Stevia rebaudiana Bertoni with great application in the food industry due to their stability against heat and wide $\mathrm{pH}$ range. Stevioside is the glycoside present in greater quantity in the Stevia leaves. It is 150 to 300 times sweeter than sucrose, but it has a strong bitter aftertaste. Rebaudioside A is the plant's second greatest sweetening component, and it is 250 to 400 times sweeter than sucrose (MIOTTO; MACHADO; FERNANDES, 2004). These sweeteners are not able to be metabolized and are anticariogenic, which makes them interesting from an alimentary point of view (REZENDE et al., 2004).

Consumer preference is usually heterogeneous, and the average values obtained cannot accurately represent the individual opinion of each consumer (ARES; GIMÉNEZ;

Received 5/13/2013

Accepted 7/28/2013 (006093)

${ }^{1}$ Instituto Federal do Triângulo Mineiro - IFTM, Campus Uberaba, Rua João Batista Ribeiro, 4000, CEP 38064-790, Uberaba, MG, Brasil, e-mail: mariana@iftm.edu.br

${ }^{2}$ Departamento de Alimentos e Nutrição, Faculdade de Engenharia de Alimentos, Universidade Estadual de Campinas - UNICAMP, Campinas, SP, Brasil

${ }^{*}$ Corresponding author 
GÁMBARO, 2006). Usually after carrying out affective tests, the data is statistically analyzed with the analysis of variance and mean comparison tests. Thus, for each product evaluated, an average is obtained for the group of consumers assuming that all respondents have the same behavior. In order to analyze the affective data, taking into consideration the individual response of each consumer and not only the average of the group of consumers that evaluated the products, the technique entitled Internal Preference Mapping was developed (SALES et al., 2008).

Segmentation is a key point in sensory studies assessing consumers, and the Internal Preference Mapping technique is a tool for exploring and understanding the structure and tendencies of consumers' preferences (MIQUELIM; BEHRENS; LANNES, 2008). The Internal Preference Mapping technique uses a multivariate statistical analysis to obtain, in a multidimensional space, a graphic representation of the differences in acceptance among the products, identifying the individual and his or her preferences. It also allows identification of the samples that were most accepted by the majority of the panelists and, considering the individuality of each tester, it characterizes groups with different preferences and consumption patterns. The Internal Preference Map is constructed with acceptance data generated from affective tests from a team of consumers (OLIVEIRA et al., 2004; LOVELY; MEULLENET,2009).

The consumers' intent to purchase depends on how much they expect the product to satisfy their expectations regarding its use. During the purchasing process, the first interaction between the consumer and the product is simply visual, i.e., packaging design characteristics may or may not attract the consumer attention, resulting in the decision to purchase the product. Based on this interaction, a choice and purchase will be determined, but the sensory and nutritional attributes that will confirm whether the choice was right and that may be deciding factors in purchasing the same product again (REIS et al., 2009).

Papers on sensory acceptance of foods comparing stevia extracts with different levels of rebaudioside A content are scarce. The aim of this study was to evaluate the physicochemical characteristics and sensory acceptance of acerola nectar sweetened with sucrose and other sweeteners.

\section{Materials and methods}

\subsection{Materials}

Samples of acerola nectar were prepared by diluting one part acerola pulp (Mais fruta - Jarinu, Brazil) in two parts mineral water, according to the manufacturer's instructions. The samples were sweetened with the following substances: $0.1 \%$ extracts from Stevia leaves with $40 \%, 80 \%$, and $95 \%$ rebaudioside $A ; 0.099 \%$ for the extract with $60 \%$ rebaudioside A (Steviafarma do Brasil - Maringá, Brazil); 0.016\% sucralose (Sweetmix - Sorocaba, Brazil); 0.0017\% neotame (Sweetmix - Sorocaba, Brazil), and 8\% sucrose (União - São Paulo, Brazil). The amounts of each sweetener added were previously determined by the magnitude estimation method (STONE; OLIVER, 1969). Homogenization of the samples was performed using an industrial blender (SIRE - Brusque, Brazil) for one minute, one day prior to testing.

\subsection{Methods}

\section{Physicochemical analyses}

The coloring of juice samples sweetened with different sweeteners was determined using a Hunterlab colorimeter, model: ColorQuest II. The device was calibrated using illuminant D65 $\left(6900{ }^{\circ} \mathrm{K}\right)$, and the reading was performed using a $10 \mathrm{~mm}$ quartz cuvette and illuminant $C$ at a visual angle of $10^{\circ}$ at the moment of the Regular Transmission (RTRAN) reading with the use of a white reference tile (C6299 Hunter Color Standard). The $\mathrm{pH}$ of the samples was measured using a potentiometer, Orion Expandable Ion Analyzer EA 940, according to the AOAC official method 981.12 (ASSOCIATION..., 2005). The total titratable acidity was determined by titration with $\mathrm{NaOH}$ according to the $\mathrm{AOAC}$ official method 942.15 (ASSOCIATION..., 2005), and the results were expressed in \% citric acid. The analysis of soluble solids in the samples, in ${ }^{\circ}$ Brix, was performed using a Carl Zeiss 844976 refractometer, according to the AOAC official method 932.12 (ASSOCIATION..., 2005). The ascorbic acid content was determined by the Tillmans method (titrimetric), which is based on the reduction of 2,6-dichlorophenol-indophenol by ascorbic acid, according to the AOAC official method 43.065 (ASSOCIATION..., 1984), modified by Benassi and Antunes (1988) by replacing the metaphosphoric acid solvent with oxalic acid. The physicochemical determinations of the acerola nectar samples were performed in triplicate.

\section{Acceptance test}

The acceptance text was conducted in the sensory analysis laboratory of the Department of Food and Nutrition at the State University of Campinas (UNICAMP). It consisted of 120 consumers, 79 women and 41 men, ages 17 to 60 , who evaluated the appearance, aroma, flavor, texture, and overall impression of the samples. Most of them (75\%) consume fruit nectar daily or 3 times a week, and $45 \%$ considered acerola nectar as their favorite. The present study was approved by the ethics committee (CAAE: 01416412.0.0000.5404). The samples were provided to the consumers in a monadic form using balanced complete block design (MACFIE, 1990) in disposable cups coded with random three-digit numbers at a temperature of $6 \pm 2{ }^{\circ} \mathrm{C}$ in individual booths under white light. A 9-cm unstructured hedonic scale anchored with (1) "would definitely not purchase" to (5) "would definitely purchase" was used (STONE; SIDEL, 1993). Purchase intent was also rated along the scale anchored with (1) "would definitely not purchase" to (5) "would definitely purchase." (MEILGAARD; CIVILLE; CARR, 2004).

\section{Result analysis}

The results of the physicochemical and sensory analyses were evaluated using Analysis of Variance (ANOVA) and the Tukey test with a confidence level of $95 \%(\mathrm{p} \leq 0.05)$. Additionally, the Internal Preference Mapping technique was applied to the 
overall impression data of the acceptance test. The statistical analyses were performed using the statistical software program SAS (Statistical Analysis System (2012) - version 8.2, Raleigh, United States of America), licensed to the State University of Campinas.

\section{Results and discussion}

Table 1 shows the results of the physicochemical analyses of the formulation of acerola nectar sweetened with various sweeteners.

The samples sweetened with stevia containing $40 \%$ and $60 \%$ rebaudioside A had a higher $\mathrm{pH}$ level, whereas the sample sweetened with sucrose had the lowest level. With respect to the content of soluble solids, the highest value was observed for the sample containing sucrose, and the lowest value for the sample containing neotame. These results are in agreement with those found by Vianna et al. (2012), who reported that the samples of orange nectar sweetened with sweeteners had lower levels of total soluble solids than those of the samples sweetened with sucrose. No significant difference was observed ( $>>0.05)$ between the samples for total titratable acidity and ascorbic acid content (Table 1).

In a study developed by Cavallini and Bolini (2005a), the lowest $\mathrm{pH}$ level was found in the mango juice sample sweetened with sucralose, and similar results were found by these authors for soluble solids and acidity. Brito et al. (2009) found no difference between the ascorbic acid content in samples of regular guava nectar and diet guava nectar.

The average values of luminosity $\left(\mathrm{L}^{*}\right)$ were lower in the sample to which sucrose was added than those of the other the samples. Regarding the colors red $\left(a^{*}\right)$ and yellow $\left(b^{\star}\right)$, the highest results found were in the nectar sample sweetened with sucralose, and the lowest value was found in the sample sweetened with sucrose (Table 1), this suggests that the addition of sucrose in acerola fruit nectar causes a decrease in the values of $\mathrm{L}^{*}, \mathrm{a}^{*}$, and $\mathrm{b}^{*}$. Cavallini and Bolini (2005a) reported higher values for luminosity and yellow color and a lower value for red in mango juice samples sweetened with sucrose. Sousa et al. (2011) found higher values for luminosity in diet mango nectar samples and higher values for the color yellow in the regular samples.

The values of soluble solids in acerola nectar sweetened with sucrose meet the standards established by Brazilian legislation (BRASIL, 2003), which establishes the minimum value of $10^{\circ}$ Brix for beverages with the addition of sucrose. All of the samples complied with the legislation in terms of acidity, ascorbic acid content, and amount of acerola pulp in the beverage BRASIL, 2003).

According to the results in Table 2, the acerola nectar samples did not differ regarding appearance and aroma. This may be related to the fact that the nectar base (pulp and water content) was the same for all samples; the only difference was the replacement of sucrose with sweeteners. The samples sweetened with sucrose and sucralose showed higher acceptance for flavor, and the samples sweetened with the extracts from stevia leaves with different rebaudioside A content levels showed significantly lower averages for this attribute, less than 5 (neither like nor dislike). This fact may be attributed to the bitter characteristic of this type of sweetener (BRITO; BOLINI, 2008a; REIS et al., 2009). Additionally, it is known that stevia masks the taste of fruit in juices and nectars (BRITO; BOLINI, 2008b; CAVALLINI; BOLINI, 2005b). For texture, the samples

Table 1. Physicochemical characteristics of acerola nectar sweetened with various sweetening agents.

\begin{tabular}{|c|c|c|c|c|c|c|c|}
\hline & $\begin{array}{c}\text { Solible solids } \\
\left({ }^{\circ} \text { Brix }\right)\end{array}$ & $\begin{array}{c}\text { Titratable acidity } \\
(\%)\end{array}$ & $\begin{array}{l}\text { Ascorbic acid } \\
(\mathrm{mg} / 100 \mathrm{~mL})\end{array}$ & $\mathrm{pH}$ & $\mathrm{L}^{*}$ & $a^{*}$ & $\mathrm{~b}^{*}$ \\
\hline Sucrose & $10.03 \pm 0.21^{\mathrm{a}}$ & $0.225 \pm 0.009^{\mathrm{a}}$ & $488 \pm 29^{a}$ & $3.39 \pm 0.02^{\mathrm{b}}$ & $35.94 \pm 0.14^{\mathrm{b}}$ & $13.37 \pm 0.13^{\mathrm{c}}$ & $12.30 \pm 0.11^{c}$ \\
\hline Stevia $40 \%$ & $2.97 \pm 0.11^{b, c}$ & $0.258 \pm 0.013^{\mathrm{a}}$ & $524 \pm 19^{a}$ & $3.58 \pm 0.01^{\mathrm{a}}$ & $36.92 \pm 0.18^{\mathrm{a}}$ & $13.70 \pm 0.05^{\mathrm{b}, \mathrm{c}}$ & $13.02 \pm 0.05^{\mathrm{b}}$ \\
\hline Stevia $60 \%$ & $2.93 \pm 0.11^{\mathrm{b}, \mathrm{c}}$ & $0.250 \pm 0.031^{\mathrm{a}}$ & $530 \pm 47^{a}$ & $3.57 \pm 0.01^{\mathrm{a}}$ & $36.70 \pm 0.39^{\mathrm{a}, \mathrm{b}}$ & $13.66 \pm 0.15^{\mathrm{b}, \mathrm{c}}$ & $12.97 \pm 0.20^{\mathrm{b}}$ \\
\hline Stevia $80 \%$ & $3.20 \pm 0.10^{\mathrm{b}}$ & $0.220 \pm 0.005^{\mathrm{a}}$ & $529 \pm 46^{a}$ & $3.46 \pm 0.05^{\mathrm{a}, \mathrm{b}}$ & $36.81 \pm 0.37^{a}$ & $13.81 \pm 0.17^{\mathrm{b}}$ & $12.99 \pm 0.28^{\mathrm{b}}$ \\
\hline
\end{tabular}

${ }^{\star}$ Means in a column followed by different letters are significantly different $(\mathrm{p} \leq 0.05)$.

Table 2. Acceptance averages ${ }^{\star}$ for acerola nectar samples.

\begin{tabular}{|c|c|c|c|c|c|}
\hline Attributes & Appearance & Aroma & Flavor & Texture & Global impression \\
\hline Sucrose & $6.27^{\mathrm{a}}$ & $5.93^{\mathrm{a}}$ & $6.42^{\mathrm{a}}$ & $6.40^{\mathrm{a}}$ & $6.42^{\mathrm{a}}$ \\
\hline Stevia $40 \%$ rebaudioside A & $6.15^{\mathrm{a}}$ & $5.70^{\mathrm{a}}$ & $3.97^{\mathrm{c}}$ & $5.57^{\mathrm{b}}$ & $4.64^{c}$ \\
\hline Sucralose & $6.37^{\mathrm{a}}$ & $6.04^{\mathrm{a}}$ & $6.42^{\mathrm{a}}$ & $6.45^{\mathrm{a}}$ & $6.60^{\mathrm{a}}$ \\
\hline Stevia $80 \%$ rebaudioside A & $6.02^{\mathrm{a}}$ & $5.77^{\mathrm{a}}$ & $4.30^{c}$ & $5.47^{\mathrm{b}}$ & $4.80^{c}$ \\
\hline Neotame & $6.42^{\mathrm{a}}$ & $6.03^{\mathrm{a}}$ & $5.17^{\mathrm{b}}$ & $6.32^{\mathrm{a}}$ & $5.61^{\mathrm{b}}$ \\
\hline
\end{tabular}

${ }^{\star}$ Means in a column followed by different letters are significantly different $(\mathrm{p} \leq 0.05)$. 
to which sucrose was added, sucralose and neotame had higher average values, in contrast to the samples sweetened with extracts from stevia leaves. Regarding overall impression, the samples sweetened with stevia extracts had lower acceptance, with averages below of 5 (neither like nor dislike), whereas the samples sweetened with sucrose and sucralose were the most accepted.

Marcellini, Chainho and Bolini (2005) and Brito and Bolini (2008a) reported no significant difference for appearance in samples sweetened with different sweeteners and sucrose in concentrated reconstituted pineapple and juice and guava nectar, respectively. Regarding aroma, Marcellini, Chainho and Bolini (2005) found no difference among samples of reconstituted pineapple juice, while Brito and Bolini (2008a) reported that the samples of guava nectar sweetened with sucrose, sucralose, and aspartame had the highest average values for this attribute.

In a study performed by Sousa et al. (2011), regular samples of mango nectar had higher average values for flavor than diet samples. Fernandes et al. (2009) observed that samples of guava nectar sweetened with sucrose and aspartame were more accepted in terms of flavor, while the sample to which stevia was added had lower acceptance for this attribute.
Addition of stevia resulted in lower acceptance for overall impression in samples of guava nectar, and the greatest acceptance was observed in samples sweetened with sucrose, sucralose and aspartame (BRITO; BOLINI, 2008a). In pineapple juice reconstituted, the greatest acceptance for overall impression was observed for sucralose, and the least for stevia (MARCELLINI; CHAINHO; BOLINI, 2005). In a study on different sweetening agents in guava nectar, Fernandes et al. (2009) reported that the samples sweetened with sucrose and aspartame had greater acceptance for overall impression.

Figure 1 shows the Internal Preference Map of the samples of acerola nectar; it was built aiming at considering the individual preference of each of the 120 consumers. The first and second dimensions generated jointly explain $55.85 \%$ of the variability among the individuals regarding acceptance of the different samples. On the right side of the map, it can be observed the presence of the samples sweetened with sucrose, sucralose, and neotame that represent consumers' preferences. In this map, the area close to these three samples was corroborated by the results of the Tukey test, in which sucralose and sucrose were the most accepted, followed by neotame. The samples sweetened with stevia containing $60 \% .80 \%$, and $95 \%$ rebaudioside A showed an

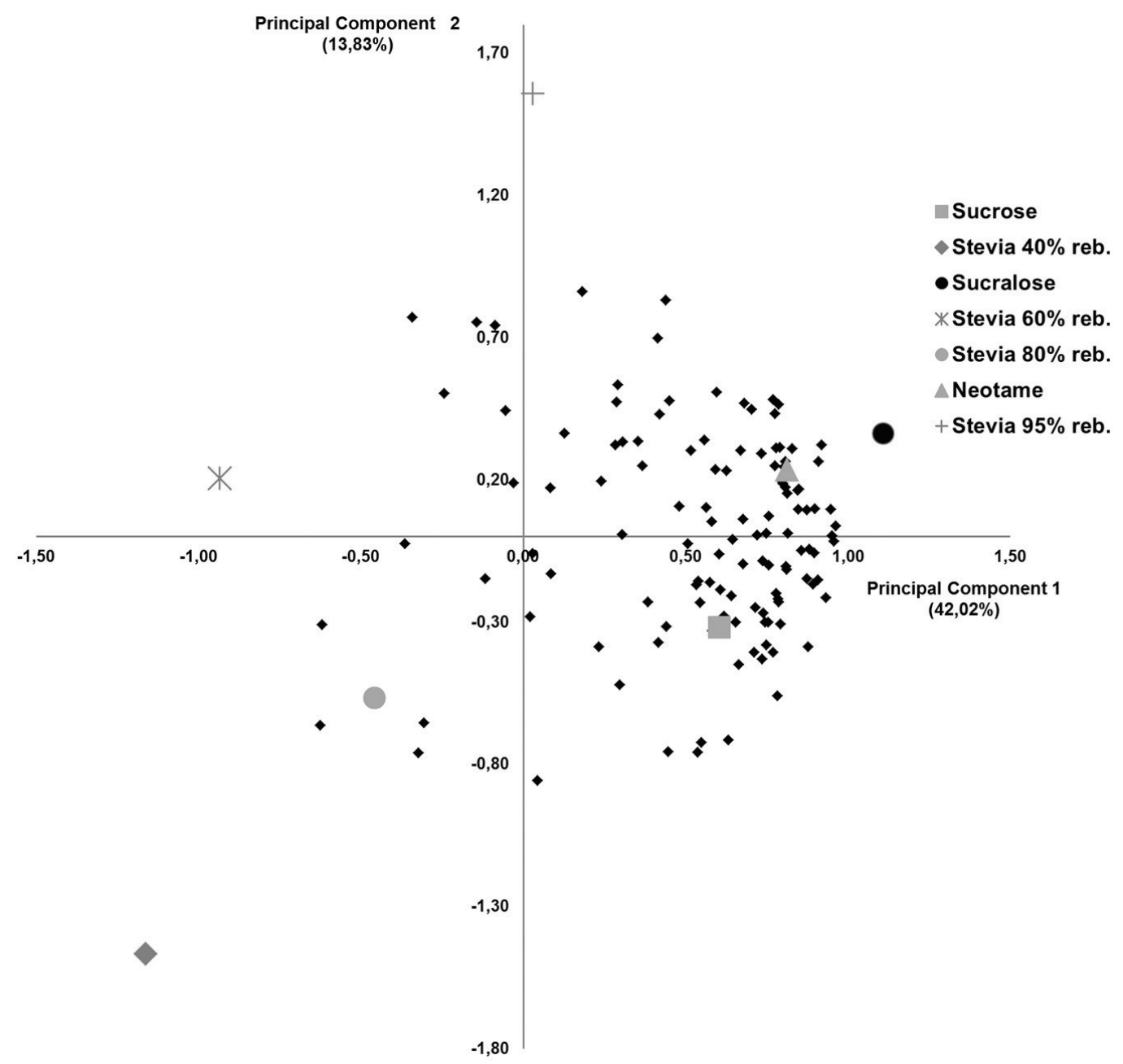

Figure 1. Internal Preference Mapping of acerola nectar samples sweetened with sucrose and different sweeteners. 
intermediate acceptance, which can be observed by the smaller area that shows consumers' preferences or by the distance from the other samples. Finally, a great distance between the large area that represents consumers 'preferences and the most accepted samples sweetened with stevia and $40 \%$ rebaudioside A can be observed; this sample was the least accepted by the consumers. Although it did not differ from the other samples sweetened with stevia in terms of overall impression. The internal preference map indicates clear acceptance of acerola nectar samples that were not sweetened with extracts from stevia leaves by the consumers. However, there is a group of consumers who prefer stevia for being a natural sweetener, and they are willing to have products with poor sensory quality by avoiding the consumption of synthetic sweeteners (SILVIA, 2011).

Brito and Bolini (2008a) reported that, in the internal preference map, the guava nectar samples sweetened with sucrose, sucralose, aspartame, and cyclamate/saccharin (2:1) were closer to each other and had a high concentration of consumers, while the sample sweetened with stevia was the least accepted. Fernandes et al. (2009) found, in the internal preference map, a great proximity between the guava nectar samples sweetened with aspartame and sucrose, which were the most accepted.
Figure 2 shows the frequency of responses for purchase intent of acerola nectar.

The purchase intent results showed that the samples of acerola nectar sweetened with sucrose and sucralose had the highest frequencies of positive purchase intent, corresponding to the responses "I would certainly buy" and "I would probably buy", totaling $67.49 \%$ and $63.33 \%$, respectively. Indecision about purchase intent, represented by the term "Maybe I would buy", showed the highest frequency of responses for the sample sweetened with stevia with $40 \%$ rebaudioside A (29.17\%), followed by the sample sweetened with neotame (26.67\%). The stevia samples with the addition of $60 \%$ and $80 \%$ rebaudioside A had the highest frequency, $55.83 \%$ and $50 \%$, respectively, of negative responses of purchase intent, which correspond to the responses "I would probably not buy" and "I would certainly not buy" (Figure 2).

Samples of conventional mango nectar showed a greater percentage of positive responses for purchase intent in comparison to those of diet samples, according to a study conducted by Sousa et al. (2011). In a study evaluating different sweeteners in guava nectar, Brito and Bolini (2008a) observed that the highest frequency of positive responses for purchase intent occurred for the sample sweetened with sucralose, whereas the sample sweetened with stevia showed the highest frequency of negative responses for purchase intent.

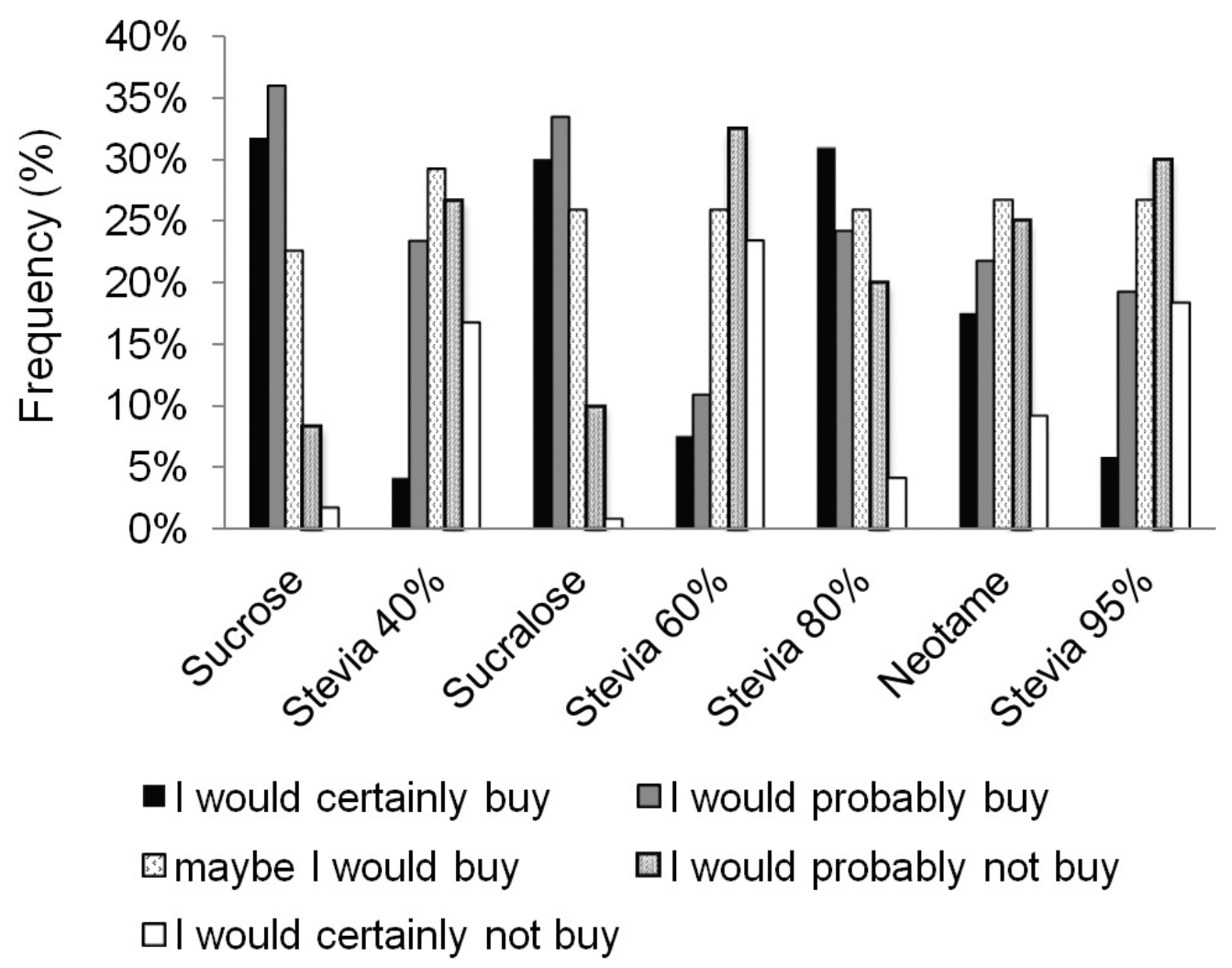

Figure 2. Distribution of the frequency of responses of purchase intent of the samples of acerola nectar. 


\section{Conclusions}

Acerola nectar samples differed in terms of physicochemical parameters, $\mathrm{pH}$, soluble solids, and color, and the sample sweetened with sucrose had lower $\mathrm{pH}$ and higher content of soluble solids. In the acceptance test, there was no significant difference for appearance and aroma, while in terms of flavor and overall impression, the most accepted samples were those sweetened with sucrose and sucralose. For texture, the greatest acceptance was observed for neotame, sucrose, and sucralose.

According to the results of the Internal Preference Map, the samples containing sucralose and neotame were similar to the sample with sucrose; these three samples were preferred by the consumers. The sample sweetened with stevia with $40 \%$ rebaudioside $\mathrm{A}$ showed strong rejection by the consumers. Furthermore, according to the internal preference map, a difference in acceptance was observed for the samples sweetened with extracts from stevia leaves depending on the content of rebaudioside $A$.

\section{References}

ARES, G.; GIMÉNEZ, A.; GÁMBARO, A. Preference mapping of texture of Dulce de leche. Journal of Sensory Studies, v. 21, n. 6, p. 553-571, 2006. http://dx.doi.org/10.1111/j.1745-459X.2006.00082.x

ASSOCIATION OF OFFICIAL ANALYTICAL CHEMISTS - AOAC. Official methods of analysis of AOAC International. 14th ed. Arlington: AOAC, 1984. $1141 \mathrm{p}$.

ASSOCIATION OF OFFICIAL ANALYTICAL CHEMISTS - AOAC. Official Methods of Analysis of the AOAC. 18th ed. Gaithersburg: AOAC, 2005. 1094 p.

BANNWART, G. C. M. C. et al. Aplication of neotame in catchup: Quantitative descriptive and physicochemical analysis. Alimentos e Nutrição, v. 18, n. 3, p. 241-251, 2007.

BASU, S.; SHIVHARE, U. S.; SINGHT, T. V. Effect of substitution of stevioside and sucralose on rheological. spectral. color and microstructural characteristics of mango jam. Journal of Food Engineering, v. 114, n. 4, p. 465-476, 2013. http://dx.doi. org/10.1016/j.jfoodeng.2012.08.035

BENASSI, M. T.; ANTUNES, J. A. A comparison of metaphosphoric and oxalic acids as extractant solutions for the determination of vitamin C in selected vegetables. Arquivos de Biologia e Tecnologia, v. 31, n. 4, p. 507-513, 1988.

BRASIL. Instrução Normativa $n^{\circ} 12$, de 4 de setembro de 2003. Estabelece o regulamento técnico para fixação dos padrões de identidade e qualidade gerais para o suco tropical e dá outras providências. Diário Oficial da República Federativa do Brasil, Brasília, DF, 09 set. 2003.

BRITO, C. A. K.; BOLINI, H. M. A. Análise da aceitação de nectar de goiaba por testes afetivos e mapa de preferência interno. Revista Brasileira de Tecnologia Agroindustrial, v. 2, n. 1, p. 67-80, 2008a. http://dx.doi.org/10.3895/S1981-36862008000100006

BRITO, C. A. K.; BOLINI, H. M. A. Percepção temporal de doçura, amargor e sabor de fruta em nectar de goiaba adoçado com diferentes adoçantes. Revista Brasileira de Tecnologia Agroindustrial, v. 2, n. 1, p. 49-66, 2008b. http://dx.doi.org/10.3895/ S1981-36862008000100005

BRITO, C. A. K. et al. In vitro antioxidant capacity, phenolic, ascorbic acid and lycopene content of guava (Psidium guajava L.) juices and nectars. Boletim do CEPPA, v. 27, n. 2, p. 175-182, 2009.
CAVAllini, D. C. U.; BOLINI, H. M. A. Perfil sensorial de suco de manga adoçado com diferentes edulcorantes e com sacarose. Alimentos e Nutrição, v. 16, n. 4, p. 327-336, 2005 a.

CAVALLINI, D. C. U.; BOLINI, H. M. A. Comparação da percepção temporal de doçura, amargor e sabor de fruta em suco de manga reconstituído e adoçado com sacarose, mistura ciclamato/sacarina 2:1, aspartame, sucralose e estevia. Boletim do CEPPA, v. 23, n. 2, p. 361-382, 2005b.

FERNANDES, A. G. et al. Avaliação sensorial de bebidas de goiaba adoçadas com diferentes agentes adoçantes. Ciência e Tecnologia de Alimentos, v. 29, n. 2, p. 327-336, 2009. http://dx.doi. org/10.1590/S0101-20612009000200019

FLAMM, W. G. et al. Long-term food consumption and body weight changes in neotame safety studies are consistent with the allometric relationship observed for other sweeteners and during dietary restrictions. Regulatory Toxicology and Pharmacology, v. 38, n. 3, p. 144-156, 2003. http://dx.doi.org/10.1016/S0273-2300(03)00075-8

GUL, M.; AKPINAR, M. G.; DAGISTAN, E. The analysis of households' purchasing preferences for fruit juice in Turkey. Journal of Food, Agriculture and Environment, v. 10, n. 3, p. 119-123, 2012.

LOVELY, C.; MEULLENET, J. F. Comparison of preference mapping techniques for the optimization of strawberry yogurt. Journal of Sensory Studies, v. 24, n. 4, p. 457-478, 2009. http://dx.doi. org/10.1111/j.1745-459X.2009.00221.x

MACFIE, H. J. H. Assessment of the sensory properties of food. Journal of Sensory Studies, v. 4, n. 2, p. 129-148, 1990 feb. http://dx.doi. org/10.1111/j.1745-459X.1989.tb00463.x

MAIA, G. A. et al. Obtenção e avaliação de bebida de baixa caloria à base de acerola (Malpighia emarginata D.C.). Revista Ciência Agronômica, v. 34, n. 2, p. 233-240, 2003

MARCELLINI, P. S.; CHAINHO, T. F.; BOLINI, H. M. A. Doçura ideal e analise de aceitação de suco de abacaxi concentrado reconstituído adoçado com diferentes edulcorantes e sacarose. Alimentos e Nutrição, v. 16, n. 2, p. 177-182, 2005.

MEILGAARD, M. C.; CIVILLE, G.; CARR, T. Sensory Evaluation Techniques. 3. ed. New York: Boca Raton, 2004. 387 p.

MEZADRI, T. et al. Antioxidant compounds and antioxidant activity in acerola (Malpighia emarginata DC.) fruits and derivatives. Journal of Food Composition and Analysis, v. 21, n. 4, p. 282-290, 2008. http://dx.doi.org/10.1016/j.jfca.2008.02.002

MIOTTO, D. M. M.; MACHADO, N.; FERNANDES, R. C. Purificação do subproduto do processo de extração de esteviosídeo. Ciência e Tecnologia de Alimentos, v. 24, n. 1, p. 146-150, 2004. http://dx.doi. org/10.1590/S0101-20612004000100026

MIQUELIM, J. N.; BEHRENS, J. H.; LANNES, S. C. S. Analysis of Brazilian consumer preference of filled chocolate. Ciência e Tecnologia de Alimentos, v. 28, n. 2, p. 493-497, 2008. http://dx.doi. org/10.1590/S0101-20612008000200034

OLIVEIRA, A. P. V. et al. Aceitação de sobremesas lácteas dietéticas e formuladas com açúcar: Teste afetivo e mapa de preferência interno. Ciência e Tecnologia de Alimentos, v. 24, n. 4, p. 627-633, 2004. http://dx.doi.org/10.1590/S0101-20612004000400025

REIS, R. C. et al. Impacto da utilização de diferentes edulcorantes na aceitabilidade de iogurte "light" sabor morango. Alimentos e Nutrição, v. 20, n. 1, p. 53-60, 2009.

REZENDE, S. L. et al. Purificação do extrato aquoso de Stevia rebaudiana Bertoni através dos processos com zeólitas e membranas. Acta Scientiarum. Technology, v. 26, n. 1, p. 21-26, 2004. 
SALES, R. L. et al. Mapa de preferência de sorvetes ricos em fibras. Ciência e Tecnologia de Alimentos, v. 28, p. 27-31, 2008. Suplemento. http://dx.doi.org/10.1590/S0101-20612008000500005

SEDIVÁ, A.; PANOVSKÁ, Z.; POKORNY, J. Sensory profiles of sweeteners in aqueous solutions. Czech Journal of Food Sciences, v. 24, n. 6, p. 283-287, 2006.

SILVIA, A. G. M. Aproximación a la comprensión de um edulzante natural alternativo, la Stevia rebaudiana Bertoni: Producción, consumo Y demanda potencial. Agroalimentaria, v. 17, n. 32, p. 57-69, 2011.

SOUSA, V. M. C. et al. Avaliação sensorial de nectar de manga tradicional e light pelo método tempo-intensidade e aceitação do consumidor. Alimentos e Nutrição, v. 22, n. 3, p. 367-378, 2011.

STATISTICAL ANALISYS SYSTEM INSTITUTE - SAS. SAS Users guide: statistics. v.8.2e. Cary: Statistics Institute, 2012.
STONE, H.; OLIVER, S. M. Measurement of the Relative Sweetness of Selected Sweeteners and Sweetener Mixtures. Journal of Food Science, v. 34, n. 2, p. 215-222, 1969. http://dx.doi. org/10.1111/j.1365-2621.1969.tb00922.x

STONE, H.; SIDEL, J. Sensory evaluation practices. 2. ed. New York: Academic Press, 1993. 338 p.

VIBERG, H.; FREDRIKSSON, A. Neonatal exposure to sucralose does not alter biochemical markers of neuronal development or adult behavior. Nutrition, v. 27, n. 1, p. 81-85, 2011. PMid:20116214. http://dx.doi.org/10.1016/j.nut.2009.10.007

VIANNA, L. M. F. et al. Caracterização analítica de sucos e néctares de laranja adoçados com sacarose e edulcorantes. Pesquisa Brasileira em Odontopediatria e Clinica Integrada, v. 12, n. 3, p. 363-367, 2012. http://dx.doi.org/10.4034/PBOCI.2012.123.10 